\title{
INFLUENCE OF SURFACE STRUCTURE ON CORROSION BEHAVIOUR OF WELDED STAINLESS STEEL AISI 316L
}

\begin{abstract}
The work deals with influence of surface structure on corrosion behaviour of austenitic stainless steel AISI 316L welded by TIG method without filler. Surfaces of the welded stainless steel were modified by mechanical treatment methods (grinding, garnet blasting, chemical method (pickling) and combination of both methods. Experimental procedures included the use of immersion and electrochemical tests where iron chloride $\left(\mathrm{FeCl}_{3}\right)$ and sodium chloride $(\mathrm{NaCl})$ solutions were used as test electrolytes. The surfaces of the specimens were examined using light microscopy and scanning electron microscopy (SEM). Experimental results confirmed the significant influence of mechanical as well as chemical surface treatment on corrosion behaviour of the welded stainless steel AISI 316L in various chloride solutions.

Keywords: Austenitic stainless steel, potentiodynamic test, corrosion properties, immersion test, surface treatment.
\end{abstract}

\section{Introduction}

Austenitic stainless steel, in addition to its excellent corrosion resistance, mechanical properties (high ductility and high toughness) and weldability, is mainly used in environment that requires high reliability and durability of the material. These steels are sensitive to local corrosion attack such as pitting and intergranular corrosion in corrosive environments (e.g. with chlorides). Pitting resistance of stainless steel usually depends on many factors including the corrosive environment, chemical compositions and structure of the material. Corrosion resistance to local forms of corrosion is influenced by quality of the passive layer created by chemical reaction of stainless steel with oxygen at normal temperature. The protective ability is affected by metal structure, chemical composition (especially by the elements such as $\mathrm{Cr}, \mathrm{Mo}, \mathrm{Ti}, \mathrm{N}$ ) and also significantly by the surface treatment. By reducing carbon content in the stainless steel, carbide precipitation has less chance to occur during welding. Due to presence of molybdenum, AISI $316 \mathrm{~L}$ austenitic stainless steel has good plasticity and high resistance against acids and deep local corrosion [1 - 7].

Durability, quality and long-term stability of engineering products are increasingly in demand. Welding of stainless steel can influence mechanical and corrosion properties. The size and character of the heat effect depends on chemical composition of stainless steel as well as welding parameters. AISI 316L stainless steels are widely used in components designed for high temperature applications. High temperature of welding process changes the steel structure by formation of carbides, various phases, ferrite and modification of grain size. A small amount of delta ferrite is necessary to avoid the problem of hot cracking during weld solidification. Properties of oxide layers on the surface are changed too [8 - 10]. Surface treatment of austenitic stainless steel has been a major interest of many industries and researchers. Surface conditions strongly affect the passive layer quality and, consequently, intensity and character of corrosion attack. Mechanical surface treatments are commonly used in industries and believed to have better mechanical properties and corrosion resistance. Chemical surface treatment (pickling) is believed to enhance the surface purity and also increases the corrosion resistance [11 - 13]. In many cases, it is acceptable to combine mechanical and chemical treatment.

The impact of surface treatments (mechanical, mechanicalchemical) of welded AISI 316L steels on corrosion resistance is presented in this paper. Corrosion behaviour of this steel under various chloride solutions was evaluated by immersion and electrochemical test. Optical microscopy and scanning electron microscopy were used to examine the surfaces.

\section{Experimental material and surface treatment}

The austenitic stainless steel of type AISI 316L was used as experimental material. The specimens were cut and prepared from

\footnotetext{
* ${ }^{1}$ Monika Halamova, ${ }^{1}$ Tatiana Liptakova, ${ }^{2}$ Ayman Alaskari, ${ }^{3}$ Fabio Bolzoni

${ }^{1}$ Department of Materials Engineering, Faculty of Mechanical Engineering, University of Zilina, SK, E.mail: monika.halamova@fstroj.uniza.sk ${ }^{2}$ Department of Mechanical Production Technology, P. O. Box: 42325 Shuwaikh 70654, Kuwait, College of Technological Studies

${ }^{3}$ Department of Chemistry, Materials and Chemical Engineering „Giulio Natta“, Politecnico di Milano, Milano, Italy
} 
Chemical composition of the AISI 316L stainless steel

Table 1

\begin{tabular}{|c|c|c|c|c|c|c|c|c|c|c|}
\hline Element & $\mathrm{Cr}$ & $\mathrm{Ni}$ & $\mathrm{Mo}$ & $\mathrm{Mn}$ & $\mathrm{C}$ & $\mathrm{Si}$ & $\mathrm{N}$ & $\mathrm{P}$ & $\mathrm{S}$ & $\mathrm{Fe}$ \\
\hline Content element [wt.\%] & 16.51 & 10.21 & 2.10 & 0.91 & 0.013 & 0.65 & 0.015 & 0.038 & 0.006 & rest \\
\hline
\end{tabular}

the original sheet metal plate to dimension of $120 \times 60 \mathrm{~mm}$ using laser cutting and then were welded by tungsten inert gas (TIG) method with no filler. Laser cutting was carried out at a pressure of $10 \mathrm{bar}$, cutting speed of $3700 \mathrm{~mm} \cdot \mathrm{min}^{-1}$ and power of $4 \mathrm{~kW}$. The dimensions of the plate were selected to ensure the ease and homogeneity of the welding process. The chemical composition of the AISI $316 \mathrm{~L}$ is listed in Table 1 where carbon content is quite low since very good weldability is required. The specimens were prepared for light microscopy in both transverse and longitudinal directions using wet grinding and etching in the solution of $10 \mathrm{ml}$ of $40 \% \mathrm{HF}, 30 \mathrm{ml}$ of $65 \% \mathrm{HNO}_{3}$ and $20 \mathrm{ml}$ glycerine.

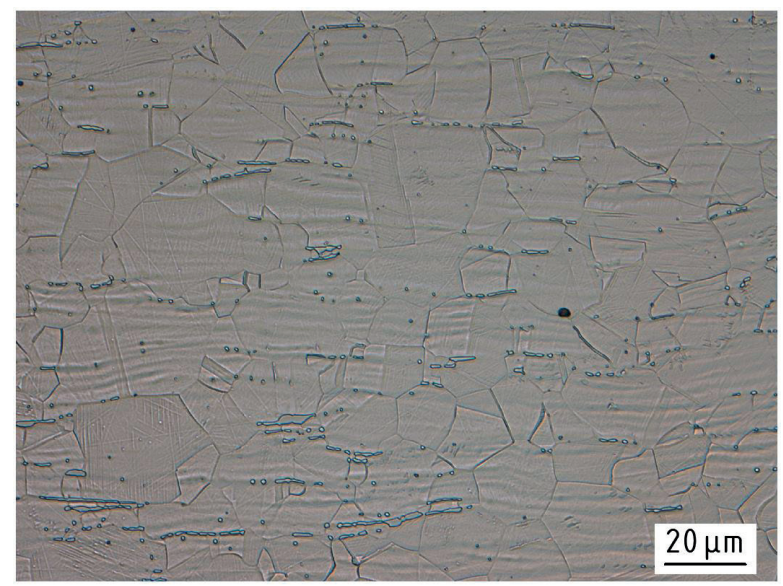

a) transverse

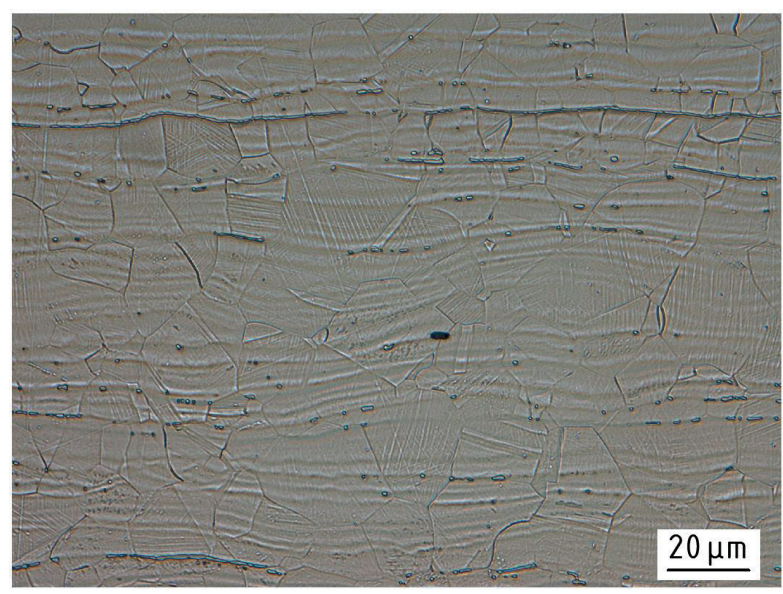

b) longitudinal

Fig. 1 The microstructure of the used AISI 316L stainless steel in different directions
Figure 1 shows the microstructure of the tested material in both directions, which is created by austenitic polyhedric grains with row deformation texture and deformation twins. In longitudinal section, deformation texture is very strong and there is present delta ferrite and inclusions.

All surfaces of the plates were degreased to ensure better weld quality. Then two plates were welded together using TIG method without filler. Welding parameters are shown in Table 2. During the welding process, argon gas was used for both sides (top and bottom) of the weld to provide a complete protection against oxidation of the welding area. Dimension of tested specimen was $50 \times 25 \mathrm{~mm}$ with thickness $3 \mathrm{~mm}$.

Welding parameters of the used TIG method without filler Table 2

\begin{tabular}{|c|c|c|}
\hline Electrode diameter $[\mathrm{mm}]$ & Used current $[\mathrm{A}]$ & Argon flow [1/min] \\
\hline 1.6 & 92 & 7 \\
\hline
\end{tabular}

Surfaces of the specimens were treated mechanically by grinding and garnet blasting. Initial surface grinding was performed to level up the surface of the welded area with base material. This was done by using surface grinding with $\mathrm{Al}_{2} \mathrm{O}_{3}$ belt with grit of 80. Then each specimen was ground by $\mathrm{Al}_{2} \mathrm{O}_{3}$ belt with grit of 180 for 3-4 minutes. This provided the welded surface with better surface finishing and better roughness. Blasting was performed on specimens with pressure of 6 bar and garnet abrasive grit of 80 (31 wt.\% $\mathrm{SiO}_{2}, 21.6$ wt.\% $\mathrm{Al}_{2} \mathrm{O}_{3}, 37$ wt.\% $\mathrm{FeO}$, and 7.4 wt.\% $\mathrm{MgO})$. The blast pointed at 90 degree angle and lasted for about 60 seconds for each specimen. In addition, three specimens from each group (grinding, garnet blasting) were pickled for 30 minutes at temperature of $22 \pm 2{ }^{\circ} \mathrm{C}$ in solution with composition $100 \mathrm{ml}$ of $50 \% \mathrm{HNO}_{3}, 5 \mathrm{ml}$ of $38 \% \mathrm{HF}, 395 \mathrm{ml}$ of distilled $\mathrm{H}_{2} \mathrm{O}$. These specimens were cleaned and rinsed with distilled water and then left for sufficient time to dry out. All specimens were weighted to determine weight loss after corrosion test. The effects of different treated surfaces were investigated by scanning electron microscope (SEM) and the EDX chemical analysis.

\section{Results and discussion}

Surfaces of the specimens with different finishing were analysed with use of SEM on the JEOL JSM-7600F electron microscope (INCA Suite version 4.13 software). The tested surfaces in the weld locality were analysed and compared. In Fig. 2 there are shown the surfaces of welded joints after different 


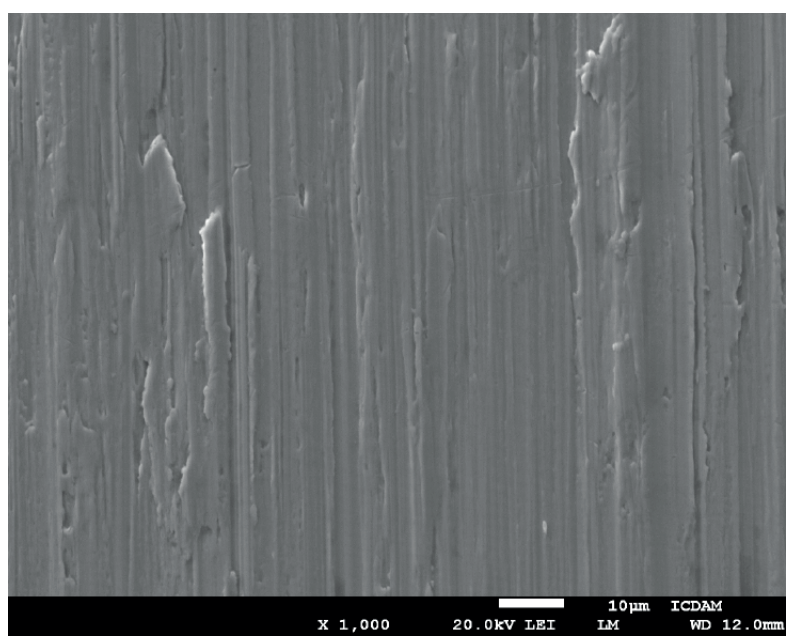

a) ground welded joint

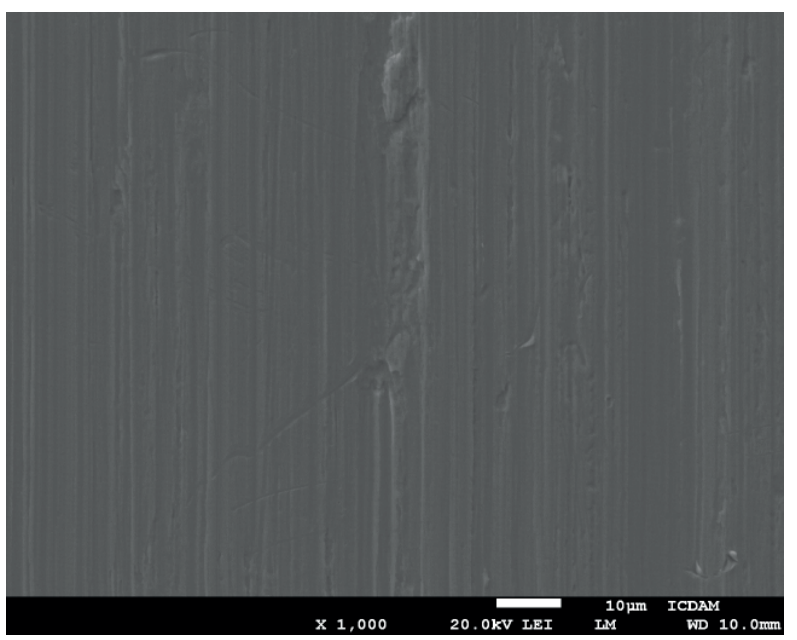

c) ground welded joint after pickling

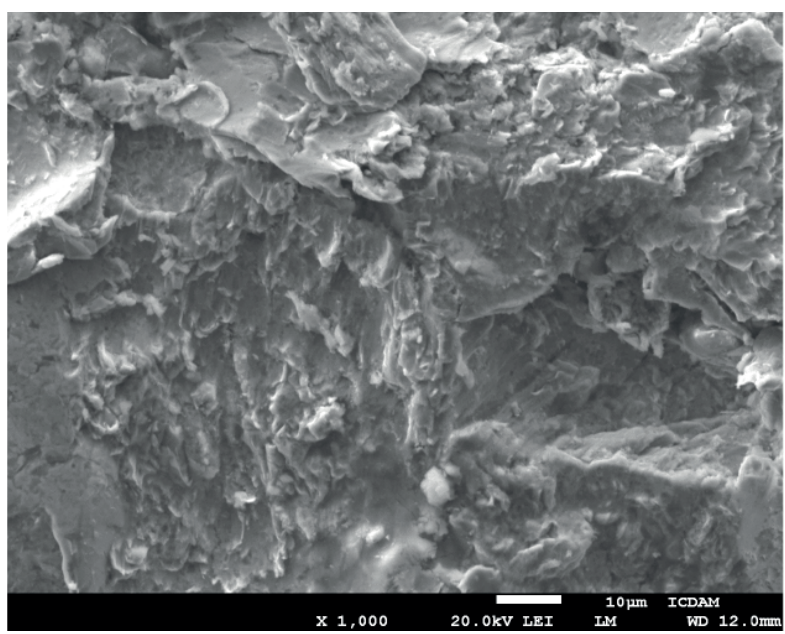

b) blasted welded joint

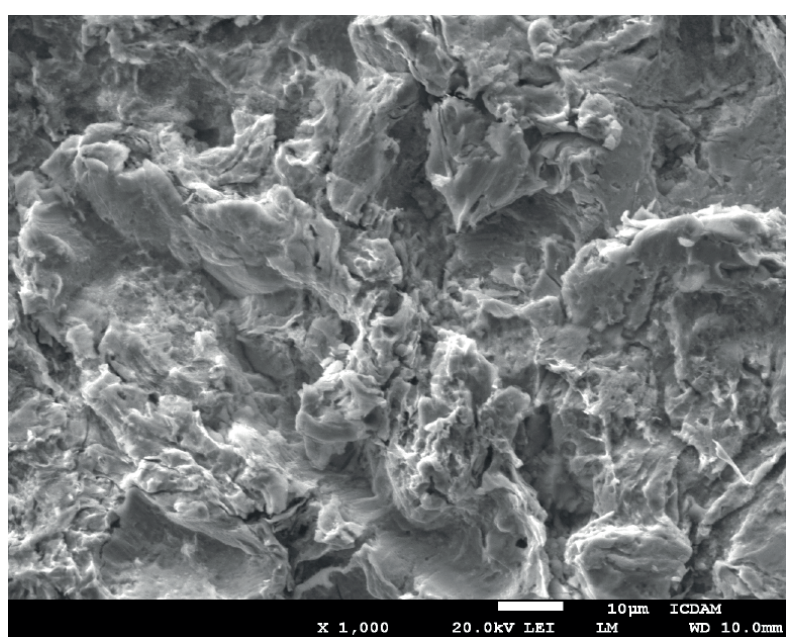

d) blasted welded joint after pickling

Fig. 2 SEM image of weld surfaces with mechanical $(a, b)$ and mechanical-chemical $(c, d)$ treatments

Chemical composition of the surfaces after various finishing

Table 3

\begin{tabular}{|c|c|c|c|c|}
\hline \multirow{2}{*}{$\begin{array}{c}\text { Surface treatment } \\
\text { Elements }\end{array}$} & ground & ground + pickled & blasted & blasted + pickled \\
\cline { 2 - 5 } & 2.39 & 1.06 & 11 & 7.65 \\
\hline $\mathrm{O}$ & 0 & 0 & 0.86 & 0.54 \\
\hline $\mathrm{Mg}$ & 0.53 & 0.42 & 1.62 & 1.46 \\
\hline $\mathrm{Al}$ & 0.67 & 0.69 & 2.87 & 1.66 \\
\hline $\mathrm{Si}$ & 0.01 & 0.05 & 0.06 & 0.01 \\
\hline $\mathrm{S}$ & 0 & 0 & 0.47 & 0.2 \\
\hline $\mathrm{Ca}$ & 16.25 & 16.78 & 15.38 & 17.77 \\
\hline $\mathrm{Cr}$ & 67.33 & 67.81 & 56.7 & 61.3 \\
\hline $\mathrm{Fe}$ & 9.57 & 10 & 8.83 & 7.16 \\
\hline $\mathrm{Ni}$ & 2.37 & 2.28 & 1.53 & 1.57 \\
\hline $\mathrm{Mo}$ & 0.88 & 0.91 & 0.7 & 0.69 \\
\hline $\mathrm{Mn}$ & & & & \\
\hline
\end{tabular}


mechanical and mechanical-chemical finishing. The EDX chemical analysis was used to determine chemical composition of the surface. The differences in chemical composition between surfaces of welded metal finished by various treatments are shown in Table 3. By grinding the smooth and unite surface was achieved and pickling increased its purity. The surface roughness after blasting was high, pickling partially increased its purity, roughness and opened cracks.

Resistance to pitting corrosion of the AISI 316L welded specimens with various surface treatments (mechanical or mechanical-chemical) was tested. The immersion test was conducted using $6 \% \mathrm{FeCl}_{3}$ solution according to the standard ASTM G 48. The environment temperature during the test was 21 ${ }^{\circ} \mathrm{C}$. After exposition in the test solution ( 72 hours) the specimens were removed from the immersion vessel, cleaned with distilled water and dried. Specimens were weighted on an analytical balance with the accuracy of $10^{-5} \mathrm{~g}$ and the corrosion rates were calculated. Results of immersion test are listed in Table 4.

Grinding surface after welding showed lower corrosion rate (Table 4a) in comparison with garnet blasted one. For the chemical treated surfaces in Table $4 \mathrm{~b}$ the same trend of corrosion rates was observed. Chemical treatment (pickling) improved the corrosion resistance of ground specimens (increase by 14\%) when compared to specimens which were not treated chemically. Pickling increased purity and homogeneity of the surface which influenced quality of the passive layer and its better protection properties. In the case of specimens after garnet blasting, pickling negatively affected their corrosion resistance and the corrosion rate increased by about $43 \%$. The garnet blasting created a rougher surface, subsurface deformation. Oxidation products of welding and blasted particles were infiltrated into subsurface layers of steel. These phenomena escalated the corrosion process. Pickling partially removed blasting agents and oxides from surface and subsurface, but cracks created by peeling of material layers (caused by garnet blasting) were enlarged by pickling [14]. The roughness of the surface increased, thereby the real reaction area also increased. It supported reduction of the $\mathrm{Fe}^{+3}$ which is the main controlling process of corrosion. Also cracks are very sensitive places to corrosion attack because the access of oxygen into the cracks is more difficult and regeneration of passive layer is reduced. These circumstances affected negatively corrosion resistance of the AISI $316 \mathrm{~L}$ stainless steel.

Corrosion rates of the AISI 316L stainless steel in $6 \% \mathrm{FeCl}_{3}$ solution

Table 4

\begin{tabular}{|c|c|c|}
\hline $\begin{array}{c}\text { Type of surface } \\
\text { treatment }\end{array}$ & $\begin{array}{c}\text { Average weight } \\
\text { losses [g] }\end{array}$ & $\begin{array}{c}\text { Average corrosion } \\
\text { rates }\left[\mathrm{g} \times \mathrm{m}^{-2} \times \mathrm{h}^{-1}\right]\end{array}$ \\
\hline grinding & 0.28204 & 3.134 \\
\hline garnet blasting & 0.39604 & 4.400 \\
\hline \multicolumn{3}{|c|}{ a) No chemical treatment } \\
\hline
\end{tabular}

\begin{tabular}{|c|c|c|}
\hline $\begin{array}{c}\text { Type of surface } \\
\text { treatment }\end{array}$ & $\begin{array}{c}\text { Average weight } \\
\text { losses [g] }\end{array}$ & $\begin{array}{c}\text { Average corrosion } \\
\text { rates }\left[\mathrm{g} \times \mathrm{m}^{-2} \times \mathrm{h}^{-1}\right]\end{array}$ \\
\hline grinding + pickling & 0.23387 & 2.599 \\
\hline $\begin{array}{c}\text { garnet blasting + } \\
\text { pickling }\end{array}$ & 0.56692 & 6.299 \\
\hline \multicolumn{2}{|c|}{ b) With chemical treatment } \\
\hline
\end{tabular}

Corrosion experiments realized by potentiodynamic polarization method were performed at $20 \pm 2{ }^{\circ} \mathrm{C}$ in $\mathrm{NaCl}$ solution with concentration of $\mathrm{Cl}^{-} 100 \mathrm{ppm}$ and $\mathrm{pH}=7$. The reference electrode was $\mathrm{Ag} / \mathrm{AgCl} / \mathrm{KCl}_{\text {satured }}$. Set up of parameters: $\mathrm{E}_{\mathrm{i}}$ (initial potential) was the same as $\mathrm{E}_{\mathrm{OC}}$ (open circuit potential), $\mathrm{E}_{\mathrm{f}}$ (final potential) was the same as $\mathrm{E}_{\mathrm{i}}$, max. current $\mathrm{I}_{\mathrm{T}}=1 \mathrm{~mA}$, step height $10 \mathrm{mV} / \mathrm{s}$.

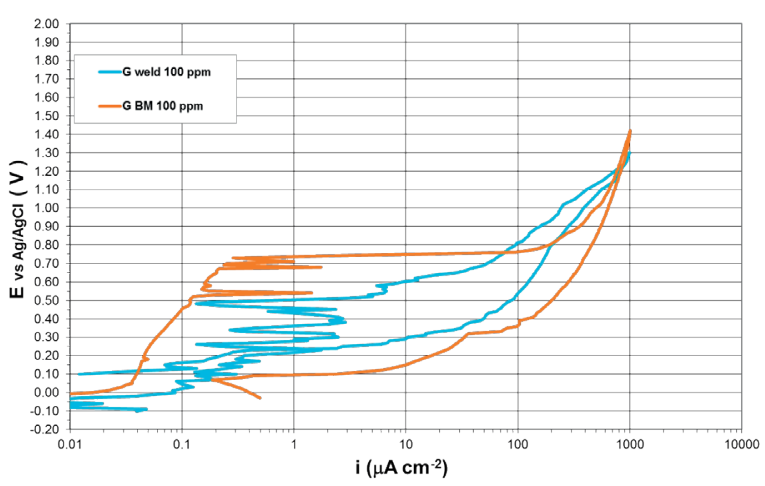

a)

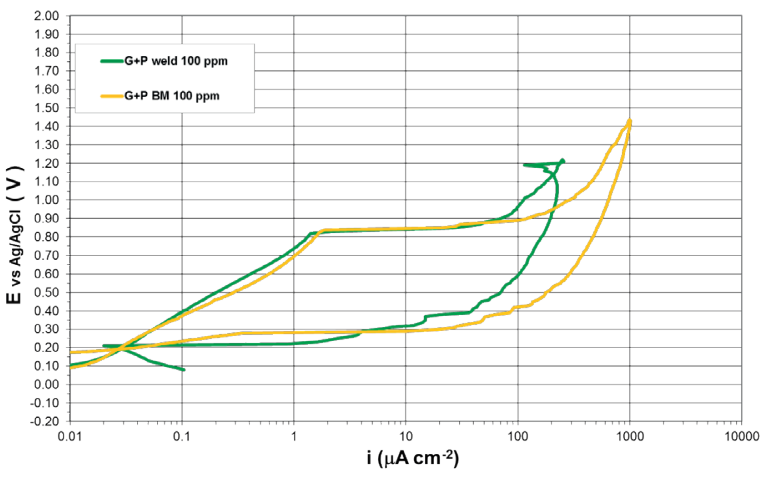

b)

Fig. 3 Comparison of electrochemical behaviour of a) ground $(G)$ and b) ground + pickled $(G+P)$ specimens in 100 ppm of $C l$ solutions for base material $(B M)$ and weld

It is well known that potentiodynamic results depend on the scanning rate and immersion time before test. Potentiodynamic tests give qualitative information on electrochemical and corrosion properties of the investigated systems [15]. Figure 3 shows the trend of the cyclic potentiodynamic curves in the solution with $100 \mathrm{ppm}$ of $\mathrm{Cl}$ for the specimens ground $(\mathrm{G})$ and ground + 
pickled $(\mathrm{G}+\mathrm{P})$. The treatment of pickling allowed a considerable improvement in localized corrosion. Electrochemical behaviour of garnet blasted $(\mathrm{S})$ and garnet blasted + pickled $(\mathrm{S}+\mathrm{P})$ for base material and weld is in Fig. 4.

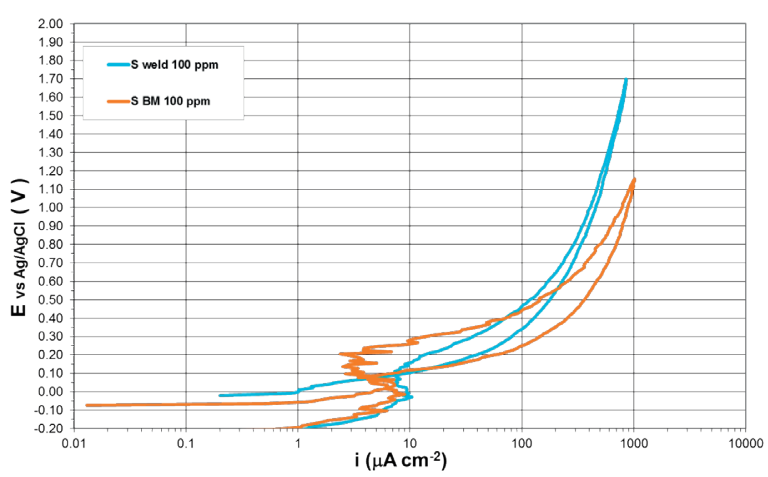

a)

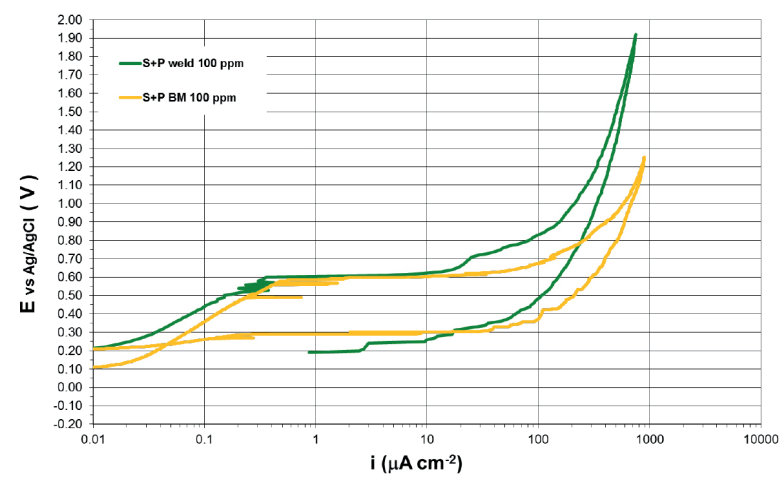

b)

Fig. 4 Comparison of electrochemical behaviour of a) garnet blasted $(S)$ and b) garnet blasted + pickled $(S+P)$ specimens in $100 \mathrm{ppm}$ of $\mathrm{Cl}$ solutions for base material (BM) and weld

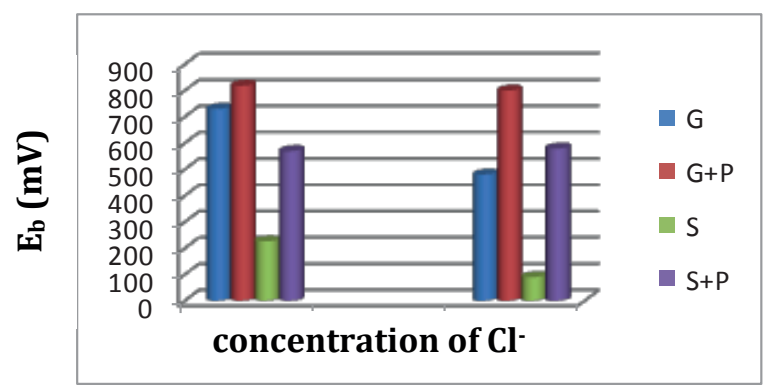

a)

b)

Fig. 5 Comparison of breakdown potential $\left(E_{b}\right)$ with various surface treatment for a) base material and b) weld in $\mathrm{NaCl}$ solution with $\mathrm{Cl}$ content $100 \mathrm{ppm}$
The graph (Fig. 5a) shows the values of breakdown potential (pitting potential) for base material in $\mathrm{NaCl}$ solution with $\mathrm{Cl}$ content $100 \mathrm{ppm}$. The specimens which were ground + pickled $\mathrm{E}_{\mathrm{b}}=818 \mathrm{mV}$ had the highest breakdown potential for solution 100 ppm, then ground $\mathrm{E}_{\mathrm{b}}=730 \mathrm{mV}$, garnet blasted + pickled $\mathrm{E}_{\mathrm{b}}=569$ $\mathrm{mV}$. The garnet blasted specimens $\mathrm{E}_{\mathrm{b}}=226 \mathrm{mV}$ had the lowest breakdown potential. The values of breakdown potential for weld are shown in graph in Fig. 5b. Weld with ground + pickled treatment had the highest breakdown potential $\mathrm{E}_{\mathrm{b}}=800 \mathrm{mV}$, then weld with garnet blasted + pickled treatment $\mathrm{E}_{\mathrm{b}}=579 \mathrm{mV}$. Weld with garnet blasted treatment $\mathrm{E}_{\mathrm{b}}=90 \mathrm{mV}$ had the lowest value of breakdown potential. The breakdown potential value for ground treatment was $\mathrm{E}_{\mathrm{b}}=480 \mathrm{mV}$. Cyclic potentiodynamic test was used for evaluation of passive layer quality. Based on the results it is obvious that mechanically treated surface after pickling became more homogenous.

\section{Conclusions}

Based on the results of this experimental work it can be concluded:

1. The welded stainless steel AISI $316 \mathrm{~L}$ treated by grinding has lower corrosion rate in comparison with garnet blasted (by about $25 \%$ ). Pickling of the ground surfaces slightly increases corrosion resistance according to results of the immersion corrosion test in the high redox potential solution. Pickling has a very positive influence on pitting corrosion characteristics of potentiodynamic experimental measurement. The surface purity achieved by pickling is reflected especially on the welds corrosion behaviour, than on the base material.

2. Based on the results of the immersion test the garnet blasting is an inappropriate method for surface treatment of the welded stainless steel AISI 316L since it accelerates corrosion in the environment with high redox potential. Blasting creates a rough surface with crevices and cracks where the aggressive solution stagnantes and the oxygen acces is restricted. Pickling even decreases corrosion resistance in this environment (by about $40 \%$ ). The surface purity of the garnet blasted specimens after pickling has positive influence according to potentiodynamic test where controlling process is metal anodic dissolution.

\section{Acknowledgements}

The research was supported by Scientific Grant Agency of Ministry of Education through VEGA grant No. 1/0066/11 and by European regional development fund and Slovak state budget by the project Research centre of University of Zilina, ITMS 26220220183. The authors thank for their support. 


\section{References}

[1] SAHLAOUI, H., et al.: Effects of Ageing Conditions on the Precipitates Evolution, Chromium Depletion and Intergranular Corrosion Susceptibily of AISI 316L: Experimental and Modeling Results. Materials Science and Engineering A 372, p. 98-108, 2004.

[2] ALVAREZ-ARMAS, I.: Duplex Stainless Steels: Brief History and Some Recent Alloys. Recent Patents on Mechanical Engineering 1 , p. $51-57,2008$

[3] SEDRIKS, A. J.: The Corrosion Monograph Series. Corrosion of Stainless Steels. A Wiley-Interscience Publication, $2^{\text {nd }}$ ed. 1996.

[4] LIPTAKOVA, T.: Pitting Corrosion of Stainless Steels (in Slovak). Zilina : EDIS. ISBN 978-80-554-0083-9, 2009.

[5] LEFFLER, B.: Stainless Steels and their Properties [online]. [cit. 2012-29-11]. Available on the internet: http://www.hazmetal. com/f/kutu/1236776229.pdf, 2012.

[6] SZKLARSKA - SMIALOWSKA, Z.: Pitting and Crevice Corrosion. Texas: NACE International. Houston. Texas. 2005.

[7] BEDDOES, J., GORDEN PARR, J.: Introduction to Stainless Steel, ASM intern., 1999.

[8] DADFAR, M. et al.: Effect of TIG Welding on Corrosion Behavior of 316L Stainless Steel. Materials Letters 61 Elsevier, p 23432346, 2007.

[9] LIPPOLD, J. C., KOTECKI, D. J.: Welding Metallurgy and Weldability of Stainless Steels. John Wiley \& Sons Inc, New Jersey. ISBN 0-471-47379-0, 2005.

[10] KOZUH, S., GOJIC, M., KOSEC, L.: The Effect of Annealing on Properties of AISI 316L Base and Weld Metals. RMZ Materials and Geoenvironment, vol. 54, No. 3, p. 331-344, 2007.

[11] BEN RHOUMA, A. et al.: Effects of Surface Preparation on Pitting Resistance, Residual Stress, and Stress Corrosion Cracking in Austenitic Stainless Steels. J. of Material Engineering and Performance (ASM International), 10, pp. 507-514, 2001.

[12] ZATKalikOVA, V., LiPTAKOVA, T.: Pitting Corrosion of Stainless Steel at the Various Surface Treatment. Materials Engineering, vol. 18, pp. 115-120., 2011.

[13] HAlAmOVA, M., LIPTAKOVA, T., ALASKARI, A.: Corrosion Resistance of AISI 316L Stainless Steel in Chloride Environment, $30^{\text {th }}$ Intern. Colloquium on Advanced Manufacturing and Repair Technologies in Vehicle Industry. Budapest : BME, 117-121, 2013

[14] LIPTAKOVA, T., FAJNOR, P., HAlAMOVA, M.: Effect of Surface Finishing on Local Corrosion of Ti-316 Stainless Steel, 29 Danubia Adria Symposium on Advances in Experimental Mechanics, ISBN 978-86-7083-762-1, Belehrad 2012, 131-132, 2013.

[15] BOLZONI, F. et al.: Electrochemical Characterization of Corrosion Resistant Alloys in Chloride Solutions. Passivation of Metals and Semiconductors, and Properties of Thin Oxide Layers, $9^{\text {th }}$ Intern. Symposium, Paris, $1^{\text {st }}$ ed. Elsevier, Marcus, P. and Maurice, V., 2006. 